\title{
Kontaminacija mliječnih proizvoda aflatoksinom M1
}

\author{
I. Varga*, B. Solomun Kolanović, I. Varenina, Đ. Božić Luburić i \\ N. Bilandžić
}

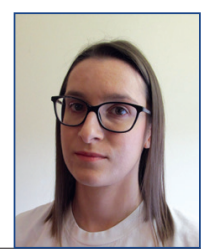

\section{Sažetak}

Aflatoksini su mikotoksini koji nastaju pod utjecajem plijesni iz roda Aspergillus. Nekoliko je vrsta aflatoksina od kojih je najtoksičniji aflatoksin B1 (AFB1). Pod utjecajem povoljnih uvjeta vlage i temperature dolazi do proizvodnje AFB1 na žitaricama, najčešće kukuruzu. Konzumiranjem takve hrane preživači unose $u$ organizam AFB1 koji se potom razgrađuje $\mathrm{u}$ aflatoksin M1 (AFM1) i izlučuje u mlijeko. Kontaminirano se mlijeko koristi u procesima proizvodnje mliječnih proizvoda. Zbog prisutnosti aflatoksina $u$ mlijeku i mliječnim proizvodima, kako bi se zaštitili potrošači sve je veći naglasak na kontroli. EU je propisala najviše dopuštene količine (NDK) za AFM1 u mlijeku od 0,05 $\mu \mathrm{g} / \mathrm{kg}$ te $\mathrm{u}$ mlijeku za dojenčad od $0,025 \mu \mathrm{g} /$ $\mathrm{kg}$. U mliječnim proizvodima nisu propisane NDK vrijednosti za AFM1, ali neke su zemlje definirale vlastite razine. U različitim istraživanjima ispitane su vrijednosti koncentracija AFM1 u mliječnim proizvodima. Utvrđeno je da su u odnosu na mlijeko od kojeg je proizvedeno sirevi imali najviše, a jogurti najniže koncentracije AFM1. Zbog prisutnosti aflatoksina $\mathrm{u}$ hrani za životinje, mlijeku i mliječnim proizvodima testiraju se različite metode kojima bi se smanjila koncentracija tih toksina.

Ključne riječi: Aspergillus, aflatoksini, aflatoksin M1, mliječni proizvodi, sir, jogurt, detoksikacija

\section{Aflatoksini}

Aflatoksini su skupina toksičnih sekundarnih metabolita nastala kao proizvod plijesni iz roda Aspergillus, naročito $A$. flavus i $A$. parasiticus (Tian i Chun, 2017.). Jako su toksični, mutageni, teratogeni i karcinogeni (Cano-Sancho i sur., 2010.). Otkriveno je približno 300 različitih vrsta aflatoksina (Shahbazi, 2017.). Riječ aflatoksin sastavljena je od 3 riječi: slova 'A' od Aspergillus genus, 'fla' od vrste flavus te 'toksin' što znači otrov (Sadeghi i sur., 2017., Saleem i sur., 2017.). Četiri su glavna aflatoksina u prirodi: B1, B2, G1 i G2. Plijesan A. flavus proizvodi aflatoksin B1 i B2, dok A. parasiticus B1, B2, G1 i G2 (Tian i Chun, 2017.).

Ovi aflatoksini identificiraju se prema boji koju fluoresciraju pod UV zračenjem

Ines VARGA*, mag. primj. kem., (dopisni autor, e-mail: varga@veinst.hr), dr. sc. Božica SOLOMUN KOLANOVIĆ, dipl. ing. preh. tehnol., dr. sc. Ivana VARENINA, dipl. ing. biotehnol., Đurđica BOŽIĆ LUBURIĆ, dipl. ing. biotehnol., dr. sc. Nina BILANDŽIĆ, dipl. ing. biotehnol., znanstvena savjetnica, Hrvatski veterinarski institut, Zagreb, Hrvatska 
(B = plava (engl. Blue)) i $(\mathrm{G}=$ zelena (engl. Green)). B1 i G1 su toksičniji od B2 i G2 (Sadeghi i sur., 2017.). Razina toksičnosti povezana s aflatoksinom varira ovisno o prisutnim tipovima, a redoslijed toksičnosti je sljedeći: AF-B1 > AF-G1 > AF-B2 > AF-G2 (Kumar i sur., 2017.). Aspergillus vrste rastu u različitim uvjetima: relativna vlažnost $88-95 \%$, temperatura $36-38{ }^{\circ} \mathrm{C}$ za rast plijesni i $25-27{ }^{\circ} \mathrm{C}$ za maksimalnu proizvodnju toksina. Svi ovi faktori utječu na rast plijesni i proizvodnju aflatoksina (Khanniri i Sohrabvandi, 2017.). Aflatoksini su prvi puta otkriveni 1960. godine u Engleskoj. Pojavom bolesti pod nazivom „Turkey X“ došlo je do smrti više od 100000 mladih purica i 20000 fazana, patki i jarebica. Uzrok ove bolesti je bio brazilski kikiriki kontaminiran s vrstom A. flavus (Sadeghi i sur., 2017.). Osim ove dvije vrste Aspergillus, neki drugi sojevi isto mogu proizvoditi aflatoksine, a među njima su $A$. nomius, $A$. tamari i $A$. pseudotamarii (Khanniri i Sohrabvandi, 2017.).

\section{Aflatoksin M1 u mliječnim proizvodima}

Aflatoksin M1 (AFM1) je 4-hidroksiliran derivat aflatoksina B1 (AFB1), relativno male molekulske mase $328 \mathrm{~g} / \mathrm{moL}$, molekulske formule $\mathrm{C}_{17} \mathrm{H}_{12} \mathrm{O}_{7^{\prime}}$ koji pokazuje blagi afinitet prema vodi (Mulunda i sur., 2013., GranadosChinchilla, 2016.). Struktura aflatoksina M1 prikazana je na slici 1. Iako je AFM1 manje toksičan u odnosu na AFB1, prema Međunarodnoj agenciji za istraživanje raka klasificiran je kao mogući humani karcinogen (dio 2B grupe) (IARC, engl. Internationl Agency for Research on Cancer) (Cano-Sancho i sur., 2010., Bilandžić i sur., 2013.).

Povišene koncentracije AFM1 $u$ mlijeku su česte u zemljama i regijama s vrućim i vlažnim klimama, u tropskim i suptropskim područjima kao što je Brazil,

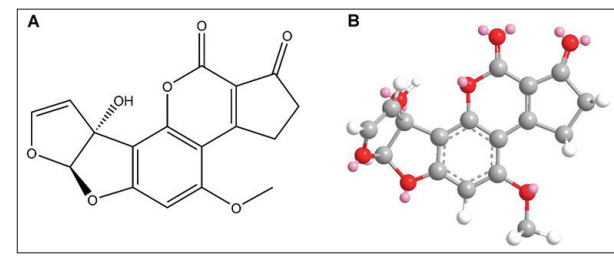

Slika 1. Aflatoksin M1 u 2D (A) i 3D (B) prikazu (Granados-Chinchilla, 2016.)

Afrika, Bliski Istok i Oceanija. Međutim, u područjima s umjerenom kontinentalnom klimom, izuzetno visoke temperature tijekom ljeta i dugi periodi suše bez kiše mogu potaknuti razvoj toksikogenih plijesni, sintezu AFB1 u kukuruzu i na taj način povećati koncentraciju AFM1 u mlijeku (Bilandžić i sur., 2017.).

Kada se preživači hrane kontaminiranom hranom, AFB1 se djelomično prije nego što uđe u krvožilni sustav razgrađuje u predželucu. Preostali dio jetra pretvara $u$ monohidroksi derivate, uglavnom AFM1, a u manjim količinama AFM2, AFM4 i druge metabolite kao što je aflatoksikol. Nakon toga se putem mliječnih žlijezda izlučuje u mlijeko. U muznih krava izlučivanje traje 12 - 24 sata nakon unosa AFB1, a vrijeme pročišćavanja iz organizma otprilike $2-3$ dana nakon što životinje konzumiraju hranu bez prisustva AFB1. Ovisno o vrsti muznih krava i količini proizvedenog mlijeka izlučena količina toksina kroz mlijeko varira između 1 i $6 \%$ uzimanog AFB1 (Serraino i sur., 2019.). Štoviše, pretpostavlja se da je prijenos AFB1 u kravlje mlijeko veći od prijenosa u ovčje i kozje mlijeko kao rezultat različite aktivnosti jetrenih enzima uključenih u u biotransformaciju AFB1 (Khanniri i Sohrabvandi, 2017.). Još jedan mogući razlog koji se spominje je držanje krava u zatvorenim prostorima. Krave se hrane žitaricama i stočnom hranom (pšenica, kukuruz) skladištenim u neprikladnim uvjetima. Takva hrana može biti kontaminirana plijesnima koji proizvode aflatoksin. Pokazalo se 
da je otvoreni uzgoj koza i ovaca na pašnjacima učinkovit faktor za smanjenje razine AFM1 u mlijeku (Shahbazi, 2017.).

Mlijeko i mliječni proizvodi imaju važnu ulogu u ljudskoj prehrani jer su bogat izvor bioraspoloživog kalcija i proteina. Međutim, mnoga prethodna istraživanja pokazala su prisutnost povišenih koncentracija AFM1 u mliječnim proizvodima (Homouda i sur., 2016.). Jedini način da osiguramo sigurnost mlijeka i mliječnih proizvoda za ljudsku uporabu je izbjegavanje kontaminacije (Shehab i sur., 2019.). AFM1 u sirovom mlijeku i mliječnim proizvodima je stabilan i uglavnom ostaje nepromijenjen procesima pasterizacije i proizvodnje vrhnja, jogurta i sira. Vjeruje se da je AFM1 u mlijeku vezan za kazein. Ovisno o vrsti ekstrakcije, svojstvima sastojaka mliječnih proizvoda, metodi obrade, razlici u kakvoći mlijeka te vrsti i stupnju kontaminacije mlijeka razina AFM1 je različita. Uspoređujući s mlijekom od kojeg je proizveden, sir sadrži više koncentracije AFM1. Ove koncentracije su 2,5 - 3,3 puta veće u mekom siru te $3,9-5,8$ puta $u$ tvrdom siru $u$ odnosu na mlijeko. Prisutnost aflatoksina u mlijeku čini poseban rizik za ljude s obzirom da ima akutne i kronične učinke na zdravlje ljudi (Sadeghi i sur., 2017.).

Prisutnost aflatoksina u siru moguća je iz tri razloga:

1. Prisutnost AFM1 u sirovom mlijeku kao posljedica prenošenja AFB1 iz kontaminirane hrane za životinje u mlijeko.

2. Sinteze aflatoksina (B1, B2, G1, G2) pod utjecajem plijesni koje rastu na siru.

3. Uporaba mlijeka u prahu koje je kontaminirano AFM1 i koje se koristi za proizvodnju sira (Akeberegn i sur., 2018.).

Mnoge vrste sira odličan su supstrat za rast plijesni. Plijesan koja raste na siru uključuje vrste Penicillium, Aspergillus,
Cladosporium, Geotrichum, Mucor i Trichoderma. Utvrđeno je da od plijesni u siru, najviše prevladavaju plijesni iz roda Penicillium (El-kest i sur., 2015.). Plijesan Penicillium camemberti i Penicillium roqueforti se odavno koriste u proizvodnji sireva s plemenitim plijesnima koji se jedu diljem svijeta. $P$. roqueforti je bitna komponenta mikroflore $\mathrm{u}$ sirevima kao što su Roquefort (Francuska), Stilton (UK), Tulum (Turska), Gorgonzola (Italija), Blauschimmelkäse (Švicarska) i Danish Blue (Danska). S druge strane, sirevi mogu biti kontaminirani s vrstom Aspergillus. Sposobnost Aspergillus vrste da proizvodi aflatoksin, tijekom rasta na Cheddar siru, prvi su opazili Lie i Marth 1967. godine. Pokazali su kako aflatoksin može prodrijeti čak $4 \mathrm{~cm}$ ispod površine sira. Prisutnost plijesni na površini sira ne znači nužno da su mikotoksini prisutni u siru. Na temelju dosadašnjih nalaza istraživanja pokazalo se da je razina onečišćenja mikotoksinom niska čak i kod sireva s pojavom plijesni. Unatoč tome preporučuje se da se kontaminirani dio sira ukloni na dubinu od najmanje 2,5 cm (O'Brien i sur., 2004.).

Rahimirad i sur. (2014.) proveli su studiju o koncentraciji AFM1 u mliječnim proizvodima. Zaključili su da godišnje doba i vrsta proizvoda ima utjecaj na razinu AFM1 u mliječnim proizvodima. Rezultati su pokazali najvišu koncentraciju AFM1 u siru i vrhnju koji su proizvedeni $u$ jesenskom i zimskom periodu. Najniža koncentracija AFM1 je bila u jogurtu tijekom svih godišnjih doba. Za ovo otkriće postoji nekoliko objašnjenja, a jedno od tog je pozitivan utjecaj bakterija mliječne kiseline na smanjenje razine AFM1 $u$ jogurtu. Prethodno je zabilježeno smanjenje do $34 \%$ koncentracije AFM1 u uzorcima jogurta u usporedbi s izvornim uzorcima sirovog mlijeka. Nadalje, pokazalo se da različiti sojevi bakterija mliječne kiseline imaju različite sposobnosti razgradnje AFM1 gdje su Lactobacillus acidophilus 
i Lactobacillus rhamnosus utjecali na smanjenje koncentracije AFM1 za 18,5 \%, odnosno 49,6 \%. Drugi razlog smanjenja AFM1 u uzorcima jogurta može biti povezan s većim afinitetom prisutnih bakterija za vezanje i razgradnju molekule AFM1 pri nižim pH vrijednostima. Otkriveno je da i koncentracija AFM1 u uzorcima vrhnja i sira bila nešto viša od one u odgovarajućim uzorcima mlijeka. Visoki udio masti u vrhnju, lipofilno svojstvo AFM1 i visok afinitet molekule AFM1 prema kazeinu mogu objasniti veću koncentraciju AFM1 u uzorcima vrhnja i sira (Rahimirad i sur., 2014.).

Sir (skuta) i sirutka proizvodi su koji se dobivaju iz mlijeka tijekom proizvodnje sira. $10 \%$ mase mlijeka pretvara se u sir, dok se preostalih $90 \%$ pretvara u sirutku (Yousefi i Hosseini, 2017.). Nekoliko studija pokazao je širok raspon raspodjele AFM1 između sira i sirutke što je ponajprije posljedica razlike $\mathrm{u}$ proizvodnom procesu (Costamagna i sur., 2019.). Jedno od takvih istraživanja proveli su Costamagna i sur. (2019.). Koncentracija AFM1 u uzorcima sirutke i sira bila je između 55,4 \% i 44,6\% ukupne količine aflatoksina prisutnog $\mathrm{u}$ mlijeku. Ovo istraživanje se podudara s još nekoliko istraživanja koja navode $u$ svome radu. Primjerice raspodjela AFM1 u svježem siru iz Argentine proizvedenom iz mlijeka koje je umjetno kontaminirano aflatoksinom M1 (u razinama 1,7 - 2,0 ng AFM1/mL) iznosi $60 \%$ u sirutki i $40 \%$ $\mathrm{u}$ siru. U siru proizvedenom u Manasu (Brazil) gdje se također koristilo umjetno kontaminirano mlijeko (0,250 i 0,500 ng AFM1/mL) prijenos AFM1 iz mlijeka u sir bio je 30,64\%, odnosno 34,91\%. Sir Camembert proizveden iz mlijeka umjetno kontaminiranog AFM1 (u koncentracijama od 0,3 do 7,5 ng AFM1/ mL) uočen je prijenos od 35,6 \% i 57,7 \% AFM1 u sir.

U prijašnjim istraživanjima ustvrđeno je da kombinirano djelovanje topline i niskog $\mathrm{pH}$ dovodi do denaturacije proteina sirutke do točke u kojoj se gubi sposobnost vezanja AFM1 i rezultira nižom koncentracijom mikotoksina $u$ sirutki. Sirutka je važan nusproizvod sira. Proteini sirutke imaju niz korisnih prehrambenih i funkcionalnih svojstava koja se koriste $\mathrm{u}$ širokom rasponu komercijalnih proizvoda kao aditivi u hrani. Ovi proizvodi mogu doprinijeti unosu AFM1 i treba procijeniti njihov utjecaj na zdravlje potrošača (Costamagna i sur., 2019.).

\section{Legislativa za aflatoksine}

$S$ ciljem ustvrđivanja prisutnosti AFM1 u mlijeku i mliječnim proizvodima uvedena je kontrola, tj. program monitoringa AFM1 u različitim zemljama. Unatoč poduzetim regulatornim mjerama kontrola proizvodnje mlijeka bez prisutnosti aflatoksina nije uvijek moguća, stoga je prisutnost AFM1 u mliječnim proizvodima, posebno $u$ siru, postala područje velikog opreza (Manetta i sur., 2009.). Zabrinutost kontaminacije mliječnih proizvoda mikotoksinima počela je prije više od 50 godina, 1960.-tih godina. Prvi prijavljeni slučaj kontaminacije AFM1 bio je u ovčjem mlijeku nakon što je stočna hrana bila kontaminirana AFB1. Ovaj jetreni hidroksilirani oblik AFB1 izvorno je nazvan „mliječni toksin". U više od 60 zemalja postoje propisi za kontrolu AFB1 u prehrambenim proizvodima.

Kako bi se smanjio rizik od bolesti uspostavljene su najveće dopuštene količine (NDK) aflatoksina M1 u mlijeku i mliječnim proizvodima (Walte i sur., 2016.). Aflatoksini su kontrolirani u više od 80 država svijeta, ali njihova legislativa nije izjednačena. Najveće dopuštene količine AFM1 u mlijeku i mliječnim proizvodima kreću se od 0 do $0,1 \mu \mathrm{g} / \mathrm{kg}$ (Vaz i sur., 2020.). Uredbom Komisije (EZ) br. 1881/2006 od 19. prosinca 2006. definirane su NDK za aflatoksin M1 u sirovom mlijeku, toplinski obrađenom mlijeku i 
Tabela 1. Najveće dopuštene količine (NDK) aflatoksina M1 u mliječnim proizvodima za različite zemlje

\begin{tabular}{|c|c|c|c|}
\hline Država & Vrsta uzorka & NDK $(\mu \mathrm{g} / \mathrm{kg})$ & Literatura \\
\hline \multirow{2}{*}{ Argentina } & mliječni proizvodi & 0,50 & $\begin{array}{l}\text { Mazumder i Sasmal, } 2001 . \\
\text { Vaz i sur., } 2020 .\end{array}$ \\
\hline & sir & 0,25 & Vaz i sur., 2020. \\
\hline Brazil & $\operatorname{sir}$ & 0,50 & Mazumder i Sasmal, 2001. \\
\hline Egipat & mliječni proizvodi & 0 & $\begin{array}{l}\text { Vaz i sur., } 2020 . \\
\text { Sadeghi i sur., } 2017 .\end{array}$ \\
\hline Honduras & sir & 0,25 & $\begin{array}{l}\text { Mazumder i Sasmal, } 2001 . \\
\text { Vaz i sur., } 2020 . \\
\text { Sadeghi i sur., } 2017 .\end{array}$ \\
\hline \multirow{2}{*}{ Iran } & maslac & 0,02 & \multirow{2}{*}{$\begin{array}{l}\text { Vaz i sur., } 2020 . \\
\text { Campagnollo i sur., } 2016 .\end{array}$} \\
\hline & $\operatorname{sir}$ & 0,25 & \\
\hline Kina & mliječni proizvodi & 0,50 & $\begin{array}{l}\text { Vaz i sur., } 2020 . \\
\text { Campagnollo i sur., } 2016 .\end{array}$ \\
\hline SAD & mliječni proizvodi & 0,50 & Campagnollo i sur., 2016. \\
\hline \multirow[t]{2}{*}{ Švicarska } & sir & 0,25 & $\begin{array}{l}\text { Mazumder i Sasmal, } 2001 . \\
\text { Campagnollo i sur., } 2016 . \\
\text { Sadeghi i sur., } 2017 .\end{array}$ \\
\hline & maslac & 0,02 & Sadeghi i sur., 2017. \\
\hline Turska & $\operatorname{sir}$ & 0,25 & $\begin{array}{l}\text { Temamogullari i Kanici, } 2014 . \\
\text { Özgören i Seçkin, } 2016 .\end{array}$ \\
\hline $\begin{array}{l}\text { Države } \\
\text { Europske Unije }\end{array}$ & Vrsta uzorka & NDK $(\mu \mathrm{g} / \mathrm{kg})$ & Literatura \\
\hline \multirow[b]{2}{*}{ Austrija } & maslac & 0,02 & \multirow{2}{*}{$\begin{array}{l}\text { Mazumder i Sasmal, } 2001 . \\
\text { Vaz i sur., } 2020 . \\
\text { Sadeghi i sur., } 2017 .\end{array}$} \\
\hline & sir & 0,25 & \\
\hline Bugarska & sir & 0,50 & Sadeghi i sur., 2017. \\
\hline Francuska & sir & 0,25 & Özgören i Seçkin, 2016. \\
\hline \multirow{3}{*}{ Hrvatska } & jogurt i voćni jogurt & 0,10 & \multirow{3}{*}{ Naredba (NN 39/2013-732) } \\
\hline & $\begin{array}{l}\text { svježi sir, namaz i } \\
\text { polutvrdi sirevi }\end{array}$ & 0,25 & \\
\hline & tvrdi sirevi & 0,45 & \\
\hline \multirow{2}{*}{ Italija } & meki sir & 0,25 & \multirow{2}{*}{ Vaz i sur., 2020.} \\
\hline & tvrdi sir & 0,45 & \\
\hline \multirow[t]{2}{*}{ Nizozemska } & $\operatorname{sir}$ & 0,20 & $\begin{array}{l}\text { Özgören i Seçkin, } 2016 . \\
\text { Sadeghi i sur., } 2017 .\end{array}$ \\
\hline & maslac & 0,02 & Sadeghi i sur., 2017. \\
\hline Rumunjska & mliječni proizvodi & 0 & Sadeghi i sur., 2017. \\
\hline
\end{tabular}


mlijeku za proizvodnju mliječnih proizvoda od 0,050 $\mu \mathrm{g} / \mathrm{kg}$ te za početnu i prijelaznu hranu za dojenčad, uključujući početno i prijelazno mlijeko za dojenčad te hranu za posebne medicinske potrebe isključivo namijenjenu dojenčadi, od 0,025 $\mu \mathrm{g} / \mathrm{kg}$ (EC, 2006.).

U EU ne postoji jedinstvena NDK vrijednost za sadržaj aflatoksina $u$ mliječnim proizvodima. Neke su zemlje uvele vlastite razine za sir (Walte i sur., 2016.). Većina zemalja koje su uspostavile ograničenja postavile su ga na $250 \mathrm{ng} /$ $\mathrm{kg}$, što odgovara pretpostavci da se sir proizvodi iz mlijeka koje je u skladu s propisima (tj. kontaminacija na razini ispod $50 \mathrm{ng} / \mathrm{kg}$ ) i da bi koncentracija AFM1 uslijed dehidratacije mogla porasti do 5 puta. Međutim, neke su se zemlje odlučile na strategiju nulte tolerancije (Rumunjska i Egipat) kako bi pružile maksimalnu zdravstvenu zaštitu potrošača na štetu proizvođača mlijeka i sira. Suprotno tome, zbog zabilježene pojave onečišćenja hrane za životinje aflatoksinom B1 i kontaminacije parmezana u 2004. godini, Italija je povećala granicu aflatoksina M1 u tvrdim sirevima na $450 \mathrm{ng} / \mathrm{kg}$ kako bi zaštitila proizvodnju ovog sira (Anfossi i sur., 2011.). NDK od 0,5 $\mu \mathrm{g} /$ $\mathrm{kg}$ ustvrđena je u većini latinoameričkih zemalja i usklađena s MERCOSURom (Mercado Común del Sur) (Urbán i sur., 2009.). U Hrvatskoj je 2013. godine donesena naredba o privremenim mjerama u odnosu na sadržaj aflatoksina M1 u mliječnim proizvodima. Pregled NDK vrijednosti po različitim zemljama prikazana je u tabeli 1 .

\section{Metode pripreme i određivanja aflatoksina}

\section{Korak ekstrakcije}

U mliječnim proizvodima ekstrakcija AFM1 predstavlja izazov i najčeće zahtijeva dodatne korake kako bi se uklonila masnoća i druge interference. Ekstrakcija AFM1 u siru se najčešće provodi korištenjem organskih otapala poput mješavine acetonitrila i vode ili metanola i vode. Međutim, mogu se koristiti i klorirana organska otapala poput diklormetana i kloroforma. Uporaba organskih otapala obično zahtijeva naknadni korak pročišćavanja prije samog određivanja. Ekstrakcija čvrstim sorbensom, poput ekstrakcije čvrstom fazom (SPE), magnetska ekstrakcija čvrstom fazom (MSPE) ili QuEChERS metoda su alternativa uporabi organskih otapala. Alternativa ekstrakciji čvrstom fazom je primjena molekularno utisnutih polimera (MIP). To su sintetički materijali koji sadrže mjesta prepoznavanja te se na njih specifično vežu ciljane molekule $u$ mješavinama s drugim spojevima (Vaz i sur., 2020.).

\section{Korak pročišćavanja}

Trenutačno najčešće korištene metode pročišćavanja su imunoafinitetne kolone (IAC) ili višenamjenske kolone za čišćenje u jednom koraku (Mycosep $\left.{ }^{\mathrm{TM}}\right)$. Ove tehnike pružaju nekoliko prednosti. Jedan primjer je izravno proćišćavanje uzoraka mlijeka na imunoafinitetnim kolonama nakon koraka odmašćivanja. Međutim, kod viskoznih ili čvrstih uzoraka kao što je sir, uvijek je potreban korak ekstrakcije. Metoda pročišćavanja pomoću imunoafinitetnih kolona pokazala se kao robusna tehnika separacije, pročišćavanja i koncentriranja AFM1 u mliječnim proizvodima (Vaz i sur., 2020.).

\section{Metode određivanja}

Nakon koraka ekstrakcije i pročišćavanja slijedi kvantifikacija aflatoksina. Tijekom proteklog desetljeća korišteno je ili razvijeno nekoliko metoda za kvantifikaciju AFM1 u mliječnim proizvodima: tankoslojna kromatografija (TLC), tankoslojna kromatografija visoke djelotvornosti (HPTLC), detekcija pomoću tekućinske kromatografije (LC) u kombinaciji s fluorescentnim (FLD), ultraljubičastim detek- 
torom (UV) ili masenim spekrometrom (MS). Bioanalize postaju sve korisnije kao postupak brzog orijentacijskog određivanja. Za određivanje AFM1 najčešće se koriste imunokemijski orijentacijski testovi uključujući ELISA metodu, imunokemijske testove koji uključuju detekciju elektrokemiluminiscentom (ECL-IA), ELISA primjenom fluorimetrijske detekcije i u novije vrijeme biosenzorsko ispitivanje. ELISA se najviše koristi za određivanje AFM1 u različitim prehrambenim matricama kao što su pasterizirano i UHT mlijeko, formula za dojenčad, mlijeko u prahu, jogurt, sladoled i sir zbog svoje jednostavnosti, osjetljivosti i prilagodljivosti. Široko se koriste brojni komercijalno dostupni ELISA kitovi (Vaz i sur., 2020.).

\section{Dekontaminacija aflatoksina iz mlijeka i mliječnih proizvoda}

Različite vrste mineralnih glina testirane su na sposobnost vezanja aflatoksina u stočnoj hrani. Ovi adsorbensi kao što su aktivni ugljen, zeolit, saponitom bogat bentonit mogu vezati aflatoksin čime se smanjuje apsorpcija AFB1 $u$ gastrointestinalnom traktu i njegovo prenošenje u mlijeko u obliku AFM1. Nedavno je istraživanje pokazalo da je bentonit učinkovit u smanjenju onečišćenja AFM1 u mlijeku na razine ispod dopuštenih europskih granica. Preostale količine bentonita $(0,4 \%)$ u malim količinama nisu imale štetne učinke na zdravlje ljudi (Assaf i sur., 2019.). Sposobnost gline za uklanjanje kontaminacije prouzročene AFM1 u kravljem mlijeku ispitana je u drugom istraživanju, uzimajući u obzir utjecaj tih glina na prehrambena svojstva mlijeka (u pogledu sastava proteina, masti i laktoze). Rezultati istraživanja pokazali su da je najmanje $65 \%$ AFM1 bilo uklonjeno iz svih uzoraka mlijeka. Bentonit se pokazao boljim adsorbensom aflatoksina M1 i B1 u odnosu na kaolin (Carraro i sur., 2014.). Bentonit je aluminijska filosilikatna glina koja postoji u dvije vrste; kalcijeva i natrijeva. Bentonit ima sposobnost vezanja toksina poput magneta, a da time ima nizak utjecaj na nutritivne osobine mlijeka (Naeimipour i sur., 2018.).

Postoji nekoliko ograničenja uporabe mineralnih adsorbensa $\mathrm{u}$ napitcima. Mogu utjecati na kakvoću, boju, teksturu te razna druga fizikalno-kemijska svojstva. Pored utjecaja na kakvoću hrane mnogi od tih adsorbensa su nespecifični, loši za okoliš i toksični pri visokim koncentracijama. Stoga su istraživanja usmjerena razvoju netoksičnih mikrobnih adsorbensa kao što su bakterije mliječne kiseline i kvasci. Uporaba probiotičkih kvasaca i bakterija mliječne kiseline $u$ vezanju aflatoksina temeljito je proučavana. Ti se biološki adsorbensi obično nalaze $u$ različitim namirnicama uključujući nekoliko mliječnih proizvoda poput mlijeka. Zbog visoke sposobnosti vezanja mikotoksina istraživači testiraju i njihovu sposobnost za vezanje AFM1 u mlijeku i drugim tekućinama. Zabilježeno je brzo vezanje za AFM1, a postotak vezanja varira prilikom promjene različitih faktora kao što su vrijeme inkubacije, temperatura, pH i koncentracija mikroorganizama. Ove metode "biokontrole" dovode do inhibicije rasta gljivica i stvaranja aflatoksina (Assaf i sur., 2019.).

Pretpostavlja se da uklanjanje aflatoksina uključuje fizičko vezanje toksina na staničnu stijenku bakterija ili komponente stanične stijenke. Polisaharid i peptidoglikan iz stanične stijenke su dva glavna elementa odgovorna za vezanje mutagena na bakterije mliječne kiseline (El-kest i sur., 2015.). Kulture Saccharomyces kefir i Lactobacillus casei pokazale su pozitivne rezultate na uklanjanje visokih koncentracija toksina u mlijeku. U 2011. godini istražena je uloga bakterija mliječne kiseline 
kao što su Lactobacillus bulgaricus i Streptococcus thermophilus za uklanjanje AFM1 u mliječnim proizvodima tijekom proizvodnje. Utvrđeno je da L. bulgaricus ima veću sposobnost vezanja i uklanjanja toksina od S. thermophilus. Enzimska razgradnja AFM1 vrstama Lactobacillus, Pseudomonas i Burkholderia također može inhibirati rast i proizvodnju aflatoksina. Kvasac Saccharomyces cerevisiae može učinkovito vezati AFM1. Među bakterijama Lactobacillus rhamnosus L60 i Lactobacillus fermentum L23 imaju visoku sposobnost inhibiranja rasta micelija aflatoksikogenih sojeva Aspergillus i smanjenja proizvodnje AFB1 (Naeimipour i sur., 2018.).

U drugom istraživanju testirana su dva soja bakterija mliječne kiseline (Lactobacillus acidophilus i Bifidobacterium lactis) na prirodno kontaminiranom mlijeku s 50,2 ppt AFM1. Nakon jednog dana koncentracija AFM1 smanjena je na 34,7 ppt (30,9\%), 22,7 ppt (54,8\%) i 18,8 ppt $(62,5 \%)$ u prisutnosti L. acidophilusa (2 \%), B. lactis $(2 \%)$ i kombinacija $L$. acidophilus $(1 \%)$ i B. lactis $(1 \%)$. U međuvremenu, najveće smanjenje koncentracije AFM1 od 10,9 ppt (78,3 \%), 4,2 ppt (91,6 \%) i 1,9 ppt (96,2\%) je postignuto primjenom istih koncentracija bakterija mliječnih kiselina nakon $48 \mathrm{~h}$. U trećem danu AFM1 nije bio detektiran (El-kest i sur., 2015.). Ova su istraživanja upozorila na važnu ulogu probiotika. Ti mikroorganizmi su sigurni, jeftini i imaju veliku potencijalnu sposobnost dekontaminacije stoga su dobri kandidati za smanjenje AFM1 u mlijeku i mliječnim proizvodima (Naeimipour i sur., 2018.).

Kemijski se procesi mogu koristiti i za smanjenje, uništavanje ili inaktivaciju aflatoksina u mlijeku. Veliki broj kemikalija poputkiselina, bazai oksidansa testirano je na razgradnju ili inaktivaciju aflatoksina. Pokazalo se da amonijak smanjuje sadržaj AFM1 u kontaminiranoj hrani za 79 - $90 \%$. To je posljedica reakcije amonijaka $\mathrm{s}$ molekulom aflatoksina i razbijanja kisikovih veza te otvaranja laktonskog prstena, čime se proizvode spojevi s nižom otrovnošću. Vodikov peroksid $\left(\mathrm{H}_{2} \mathrm{O}_{2}\right)$, kao jako oksidacijsko sredstvo, u kombinaciji $\mathrm{s}$ primjenom različitih temperatura utječe $i$ na smanjenje aflatoksina $u$ mlijeku. Primjerice, dodavanjem $\mathrm{H}_{2} \mathrm{O}_{2}$ pri temperaturi od $36{ }^{\circ} \mathrm{C}$ tijekom 30 min i kuhanjem od $5 \mathrm{~min}$ inaktivira aflatoksin za 27,8 \%. Pri temperaturi od $75{ }^{\circ} \mathrm{C}$ tijekom $15 \mathrm{~s}$ i kuhanjem 5 minuta aflatoksin se inaktivira za 28,8\%. Dodatak $\mathrm{H}_{2} \mathrm{O}_{2}$ ili natrijevog hipoklorita $\mathrm{u}$ hranu i skladištenje na sobnoj temperaturi kroz 7 dana može uništiti 62 \% i 82 \% sadržaja AFB1 (Naeimipour i sur., 2018.).

Jedna od vrlo zanimljivih metoda je korištenje ekstrakata biljki. Postoje biljke koje pokazuju učinkovitost $u$ smanjenju aflatoksina npr. brokula, češnjak, crni kumin i kurkumin jer posjeduju antioksidativna, antifungalna i protuupalna svojstva. Zabilježeno je da biljke poput kumarina, flavonoida i kurkuminoida inhibiraju biotransformaciju aflatoksina do njihovih aktivnih epoksidnih derivata. Antioksidansi poput vitamina C i E mogu se dodati hrani kako bi se spriječile reakcije oksidacije s ostalim tvarima koje su opasne za ljudske stanice. Drugim riječima antioksidansi mogu pomoći detoksiciranju toksina $u$ jetri i ostalim stanicama te posljedično smanjiti pojavu mikotoksikoze (Naeimipour i sur., 2018.).

\section{Literatura}

1. AKEBEREGN, D., T. ALEMNEH and D. ZEWUDIE (2018): Effects of Aflatoxin Contamination in Milk: A Review. Merit Res. J. Microbiol. Boil. Sci. 6, 118-128.

2. ANFOSSI, L., C. BAGGIANI, C. GIOVANNOLI and G. GIRAUDI (2011): Occurrence of Aflatoxin M1 in Dairy Products (Chapter 1). In: Torres-Pacheco, I. (ed.): Aflatoxins - Detection, Measurement and Control. InTechOpen, Rijeka, Croatia, pp. 3-20.

3. ASSAF, J. C., S. NAHLE, A. CHOKR, N. LOUKA, A. ATOUI and A. EL KHOURY (2019): Assorted Methods for Decontamination of Aflatoxin M1 in Milk Using Microbial Adsorbents. Toxins (Basel) 11, 304 . 
4. BILANDŽIĆ, N., I. VARENINA, Đ. BOŽIĆ, M. SEDAK, M. ĐOKIĆ, B. SOLOMUN KOLANOVIĆ i Ž. CVETNIĆ (2013): Aflatoksin M1 u mlijeku i mliječnim proizvodima. Vet. stn. 44, 195-203.

5. BILANDŽIĆ, N., I. VARENINA, B. SOLOMUN KOLANOVIĆ, Đ. BOŽIĆ LUBURIĆ, I. VARGA, B. ŽELJEŽIĆ, L. CVETNIĆ, M. BENIĆ, S. TANKOVIĆ and Ž. CVETNIĆ (2017): Occurrence of aflatoxin M1 in raw cow, goat and sheep milk during spring and autumn in Croatia during 2016. Toxin Rev. 36, 290-296.

6. CANO-SANCHO, G., S. MARIN, A. J. RAMOS, J. PERIS-VICENTE and V. SANCHIS (2010): Occurrence of aflatoxin M1 and exposure assessment in Catalonia (Spain). Rev. Iberoam. Micol. 27, 130-135.

7. CARRARO, A., A. DE GIACOMO, M. L. GIANNOSSI, L. MEDICI, M. MUSCARELLA, L. PALAZZO, V. QUARANTA, V. SUMMA and F. TATEO (2014): Clay minerals as adsorbents of aflatoxin M1 from contaminated milk and effects on milk quality. Appl. Clay Sci. 88-89, 92-99.

8. COSTAMAGNA, D., M. GAGGIOTTI, C.A. CHIERICATTI, L. COSTABEL, G. M. L. AUDERO, M. TAVERNA and M. L. SIGNORINI (2019): Quantification of aflatoxin $\mathrm{M}_{1}$ carry-over rate from feed to soft cheese. Toxicol. Rep. 6, 782-787.

9. EC (2006): Commission Regulation No 1881/2006 of 19 December 2006 setting maximum levels for certain contaminants in foodstuffs. Off. J. Eur. Comm. L364.

10. EL-KEST, M. M., M. EL-HARIRI, N. I. M. KHAFAGA and M. K. REFAI (2015): Studies on contamination of dairy products by aflatoxin M1 and its control by probiotics. J. Glob. Biosci. 4, 1294-1312.

11. GRANADOS-CHINCHILLA, F. (2016): Insights into the Interaction of Milk and Dairy Proteins with Aflatoxin M1 (Chapter 13). In: Gigli, I. (ed.): Milk Proteins - From Structure to Biological Properties and Health Aspects, IntechOpen, Rijeka, Croatia, pp. 265-286.

12. HOMOUDA, S. N., M. E. EL HASANIN, T. A. ABDELGHAFFAR and K. E. ELEKHNAWY (2016): Correlation Between Aflatoxin M1 in Milk and Milk Products in Dairy Animals Fed on Aflatoxin B1 Contaminated Ration. Egypt. J. Chem. Environ. Health 2, 475-489.

13. KHANNIRI, E. and S. SOHRABVANDI (2017): Mycotoxins in milk and milk products (Chapter 1). In: Mortazavian, A. M. and N. Khorshidian (eds.): Aflatoxin in milk and milk products. LAP LAMBERT Academic Publishing, Saarbrücken, Germany, pp. 1-22.

14. KUMAR, P., D. K. MAHATO, M. KAMLE, T. K. MOHANTA and S. G. KANG (2017): Aflatoxins: A Global Concern for Food Safety, Human Health and Their Management. Front. Microbiol. 7, 2170.

15. MANETTA, A. C., M. GIAMMARCO, L. DI GIUSEPPE, I. FUSARO, A. GRAMENZI, A. FORMIGONI, G. VIGNOLA and L. LAMBERTINI (2009): Distribution of aflatoxin M1 during
Grana Padano cheese production from naturally contaminated milk. Food Chem. 113, 595-599.

16. MAZUMDER, P. M and D. SASMAL (2001): Mycotoxins - Limits and Regulations. Anc Sci. Life. 20, 1-19.

17. MULUNDA, M., L. NGOMA, M. NYIRENDA, L. MOTSEI and F. BAKUNZI (2013): A Decade of Aflatoxin M1 Surveillance in Milk and Dairy Products in Developing Countries (2001-2011): A Review (Chapter 2). In: Makun, H. A. (ed.): Mycotoxin and Food Safety in Developing Countries, IntechOpen, Rijeka, Croatia, pp. 39-60.

18. Naredba NN 39/2013-732: Naredba o privremenim mjerama u odnosu na sadržaj aflatoksina M1 u mliječnim proizvodima, NN 39/2013, 732, Ministarstvo poljoprivrede, 3.4.2013.

19. NAEIMIPOUR, F., J. AGHAJANI, S. A. KOJURI and S. AYOUBI (2018): Useful approaches for reducing aflatoxin M1 content in milk and dairy products. Biomed. Biotechnol. Res. J. 2, 94-99.

20. O'BRIEN, N. M., T. P. O'CONNOR, J. O'CALLAGHAN and A. D. W. DOBSON (2004): Toxins in Cheese. In: Fox, P. F., P. L. H. McSweeney, T. M. Cogan and T. P. Guinee: Cheese: Chemistry, Physics and Microbiology, Volume 1: General Aspects. Elsevier Academic Press, Cambridge, Massachusetts, USA, pp. 561-571.

21. ÖZGÖREN, E. and A. K. SEÇKIN (2016): Aflatoxin M1 contaminations in mouldy cheese. Mljekarstvo 66, 154-159.

22. RAHIMIRAD, A., H. MAALEKINEJAD, A. OSTADI, S. YEGANEH and S. FAHIMI (2014): Aflatoxin M1 Concentration in Various Dairy Products: Evidence for Biologically Reduced Amount of AFM1 in Yoghurt. Iran J. Public Heal. 43, 1139-1144.

23. SADEGHI, E., R. MOHAMMADI and F. KARAMI (2017): Toxicity of aflatoxin in milk and milk products (Chapter 2). In: Mortazavian, A. M., N. Khorshidian (eds.): Aflatoxin in milk and milk products. LAP LAMBERT Academic Publishing, Saarbrücken, Germany, pp. 23-41.

24. SALEEM, F., B. SADIA and F. S. AWAN (2017): Control of Aflatoxin Production Using Herbal Plant Extract (Chapter 1). In: Abdulra'uf, L. B. (ed.): Aflatoxin- Control, Analysis, Detection and Health Risks, InTechOpen, Rijeka, Croatia, pp. 1-12.

25. SERRAINO, A., P. BONILAURI, K. KEREKES, Z. FARKAS, F. GIACOMETTI, A. CANEVER, A.V. ZAMBRINI and Á. AMBRUS (2019): Occurrence of Aflatoxin M1 in Raw Milk Marketed in Italy: Exposure Assessment and Risk Characterization. Front. Microbiol. 10, 2516.

26. SHAHBAZI, Y. (2017): Aflatoxin M1 Contamination in Milk and Dairy Products: Implications on Human Health (Chapter 19). In: Watson, R. R., R. J. Collier, V. R. Preedy (eds.): Nutrients in Dairy and Their Implications for Health and Disease. Elsevier Academic Press, Cambridge, Massachusetts, USA, pp. 237-250. 
27. SHEHAB, L. M., A. A. EL-LEBOUDY and H. S. ABO EL-MAKAREM (2019): Prevalence of Aflatoxins M1 and M2 in some curd dairy products. Alexandria J. Vet. Sci. 61, 140-145.

28. TEMAMOGULLARI, F. and A. KANICI (2014): Short communication: Aflatoxin M1 in dairy products sold in Şanlıurfa, Turkey. J. Dairy Sci. 97, 162-165.

29. TIAN, F. and H. S. CHUN (2017): Natural Products for Preventing and Controlling Aflatoxin Contamination of Food (Chapter 2). In: Abdulra'uF, L. B. (ed.): Aflatoxin - Control, Analysis, Detection and Health Risks. InTechOpen, Rijeka, Croatia, pp. 13-44.

30. URBÁN, G., J. PÉREZ, F. MARTÍNEZ, J. SALAS, G. DÍAZ, M.L. RAMÍREZ, G. CASTRO, S. VEGA, R. GUTIÉRREZ and A. ESCOBAR (2009): Niveles de Aflatoxina M1 en quesos frescos producidos en diferentes zonas de México. Rev. Salud Anim. 312, 115-121.

31. VAZ, A., A. C. CABRAL SILVA, P. RODRIGUES and A. VENÂNCIO (2020): Detection Methods for Aflatoxin M1 in Dairy Products. Microorganisms 8,246 .

32. WALTE, H., C. SCHWAKE-ANDUSCHUS, R. GEISEN and J. FRITSCHE (2016): Aflatoxin: food chain transfer from feed to milk. J. Verbr. Lebensm. 11, 295-297.

33. YOUSEFI, M. and H. HOSSEINI (2017): Detoxification of AFM1 in milk and milk products (Chapter 4). In: Mortazavian, A. M. and N. Khorshidian (eds.): Aflatoxin in milk and milk products. LAP LAMBERT Academic Publishing, Saarbrücken, Germany, pp. 72-103.

\section{Contamination of dairy products with aflatoxin M1}

Ines VARGA, mag. appl. chem., Božica SOLOMUN KOLANOVIĆ, PhD, Grad. Food Technology Eng., Ivana VARENINA, PhD, Grad. Biotechnology Eng., Đurđica BOŽIĆ LUBURIĆ, Grad. Biotechnology Eng., Nina BILANDŽIĆ, PhD, Grad. Biotechnology Eng., Scientific Advisor, Croatian Veterinary Institute, Zagreb, Croatia

Aflatoxins are mycotoxins produced by species of the fungal genus Aspergillus. There are several types of aflatoxins, but the most toxic is aflatoxin B1 (AFB1). Different conditions (humidity and temperature) lead to the production of AFB1 on grains, especially maize. When ruminants consume contaminated feed, AFB1 enters into the gastrointestinal tract, is metabolised into aflatoxin M1 (AFM1) and secreted into milk. This contaminated milk is then used in the production of dairy products. Due to the presence of aflatoxin in milk and dairy products, control of these toxins is important for consumer protection. In the EU, the maximum residue level (MRL) of AFM1 in milk is set to $0.05 \mu \mathrm{g} / \mathrm{kg}$ and for infant milk to $0.025 \mu \mathrm{g} / \mathrm{kg}$. However, there is no EU MRL for AFM1 in dairy products, though some countries have defined national limits. A number of studies have been carried out to determine the concentration of AFM1 in dairy products. Cheeses have the highest and yogurts the lowest concentration of AFM1, lower than the concentration in the milk from which it was produced. Due to the presence of aflatoxin in animal feed, milk and dairy products, various methods have been tested to reduce the concentrations of these toxins.

Key words: Aspergillus; aflatoxin; aflatoxin M1; dairy products; cheese; yogurt; detoxification 